\title{
Adolescent girls' health, nutrition and wellbeing in rural eastern India: a descriptive, cross-sectional community- based study
}

Kelly Rose-Clarke ${ }^{1 *}$ (D) Hemanta Pradhan², Suchitra Rath², Shibanand Rath², Subhashree Samal ${ }^{2}$, Sumitra Gagrai², Nirmala Nair ${ }^{2}$, Prasanta Tripathy ${ }^{2}$ and Audrey Prost $^{3}$

\begin{abstract}
Background: India is home to 243 million adolescents. Two million (9\%) of them belong to Scheduled Tribes living in underserved, rural areas. Few studies have examined the health of tribal adolescents. We conducted a cross-sectional survey to assess the health, nutrition and wellbeing of adolescent girls in rural Jharkhand, eastern India, a state where $26 \%$ of the population is from Scheduled Tribes. We aimed to identify priorities for community interventions to serve adolescents and their families.

Methods: Between June 2016 and January 2017, interviewers visited all households in 50 purposively sampled villages of West Singhbhum district, Jharkhand. They aimed to interview all girls aged 10-19. Interviewers conducted face-toface interviews with girls to administer a survey about physical and mental health, disability, nutrition, sexual and reproductive health, gender norms, decision-making, education and violence. Interviewers also measured girls' height, weight, and Mid-Upper Arm Circumference.

Results: Interviewers collected data from 3324 (82\%) of an estimated 4068 girls residing in the study area. Their mean age was 14.3 (SD 2.9). 82\% were from Scheduled Tribes. 89\% of younger girls aged $10-14$ and $46 \%$ of older girls aged 15-19 were in school or college. Girls dropped out of school because they were required for household work (37\%) or work on the family farm or business (22\%). Over a third reported symptoms of anaemia in the past month, but less than a fifth had a blood test. The prevalence of thinness (<-2SD median BMl for age and sex) was $14 \%$ for younger girls and $6 \%$ for older girls. $45 \%$ of girls were stunted ( $<-2$ SD median height for age and sex). 40\% reported emotional violence in the past year, $14 \%$ physical violence, and $0.7 \%$ sexual violence. $12 \%$ had problems associated with depression or anxiety. 30\% aged 15-19 had heard of contraception. Among married girls and their husbands, only 10\% had ever used methods to prevent or delay pregnancy.
\end{abstract}

Conclusions: Our study identified several priorities to improve adolescent girls' health, nutrition and wellbeing in largely tribal areas of Jharkhand: reducing violence, early marriage and undernutrition, as well as improving mental health, knowledge about contraception and school retention.

Keywords: Adolescent health, Mental health, Undernutrition, Violence, Sexual and reproductive health, Education, Menstrual hygiene, India

\footnotetext{
* Correspondence: kelly.rose-clarke@kcl.ac.uk

'Department of Global Health and Social Medicine, King's College London,

Bush House NE Wing, London WC2B 4BG, UK

Full list of author information is available at the end of the article
}

(c) The Author(s). 2019 Open Access This article is distributed under the terms of the Creative Commons Attribution 4.0 International License (http://creativecommons.org/licenses/by/4.0/), which permits unrestricted use, distribution, and reproduction in any medium, provided you give appropriate credit to the original author(s) and the source, provide a link to the Creative Commons license, and indicate if changes were made. The Creative Commons Public Domain Dedication waiver (http://creativecommons.org/publicdomain/zero/1.0/) applies to the data made available in this article, unless otherwise stated. 


\section{Background}

Global investment in adolescent health is crucial. Adolescents aged 10-19 years constitute around one sixth of the world's population, account for $6 \%$ of the global burden of disease and injury, and suffer over 1.2 million deaths each year [1]. While infant (first year of life) and childhood (1-9 years) mortality have declined substantially in the last 50 years, reductions in adolescent mortality have been more modest [2]. Poor health or risky behaviours during adolescence can have negative impacts on health in adult life [3]. In addition, childbearing in adolescence can have adverse effects across generations by increasing the risk of low birth weight and poor growth, and by perpetuating the intergenerational cycle of poverty [4]. For these reasons, the Global Strategy to Improve Women's, Children's and Adolescents' Health (2016-2030) includes a commitment to accelerate action to improve adolescent health [5].

India has the largest cohort of adolescents in the world, approximately 243 million [6]. A recent national review found that adolescents were commonly affected by both under and overnutrition, common mental disorders, substance use and violence [7]. Girls are particularly vulnerable: $45 \%$ of girls aged 15-18 have a BMI less than 18.5, and $27 \%$ of women aged 20-24 were married before the age of $18[8,9]$. Sixty-eight percent of women are literate compared to $86 \%$ of men [8]. These national figures mask important inequities across States, and between wealth and caste/tribal groups. Scheduled Tribe, or adivasi (i.e. indigenous) communities constitute $9 \%$ of India's population - over 104 million people [10]. Although concentrated in Central, Eastern and North East India, such communities exist across India. They have historically been socioeconomically disadvantaged, disproportionately affected by undernutrition, and underserved by health services [11]. Despite these inequities, there is little recent data on the health, nutrition and wellbeing of adolescents in Scheduled Tribe communities.

We aimed to assess the health, nutrition and wellbeing of adolescent girls aged 10-19 years living in a predominantly tribal area of rural Jharkhand, India. We sought to identify priorities for community intervention at the State level, with broader implications for tribal adolescent health across the country.

\section{Methods}

\section{Study design}

Between June 2016 and January 2017, we conducted a crosssectional, community-based survey of adolescent girls in West Singhbhum district, Jharkhand, a state of eastern India. This study was the baseline survey to inform the design of a cluster-randomised controlled trial (ISRCTN17206016) of an intervention to improve adolescent health with Ekjut, a civil society organisation based in Jharkhand, in partnership with University College London.

\section{Setting}

The size of the study area was chosen for logistical reasons and comprised 50 villages and their attached hamlets in Khuntpani block, West Singhbhum district, southern Jharkhand. Over a quarter of Jharkhand's population is from Scheduled Tribes [10]. The majority of the population living in our study villages were from the Ho tribe, a tribal group comprising over 1 million people, around 930,000 of whom reside in Jharkhand [12]. The Ho families in our study areas were mainly engaged in cultivation and seasonal migration for wage labour.

Because this study was the baseline survey for a cluster randomised controlled trial, the 50 villages and hamlets were grouped into 38 population clusters. Each cluster was a purposively selected geographic area with a population of around 1000 (range: 723-1962). All of the 50 study villages had an Anganwadi centre providing basic healthcare for mothers and children. Eleven out of 50 had a sub-centre usually staffed by an Auxiliary Nurse Midwife (female) and a multipurpose worker (male). Most villages (33/50) had a primary school and 19 had a secondary school.

\section{Survey methods \\ Inclusion criteria}

We aimed to interview all married and unmarried adolescent girls aged 10-19 living in the study area.

\section{Recruitment process}

An interviewer visited each household outside school hours to identify eligible girls, obtain their consent for participation as well as the consent of their caregiver, and to conduct face-to-face interviews with girls. All interviewers were female. Depending on the participant's preference, interviews were conducted in Hindi, Ho or Oriya by interviewers who were fluent in these languages. If an eligible girl was unavailable due to e.g. attending a boarding school or living in a hostel, the reason was documented. Interviewers did not make a repeat visit to the household.

\section{Survey instrument development}

Our survey instrument is provided as an additional file (Additional file 1). The instrument included questions on physical and mental health, disability, nutrition, sexual and reproductive health, gender norms, decisionmaking, education and violence. Interviewers also conducted short interviews with girls' caregivers (or girls themselves if aged 18 or older) to collect householdlevel socioeconomic data.

For some areas of adolescent health, we were able to adopt questions used in previous national surveys of adolescents in India and adolescent health indicators from the international literature [13-15]. For example, we assessed literacy by asking girls to read a standard 
sentence, as in India's National Family Health Survey. We asked about disability using the Washington Group Short Set of Disability Questions [16]. These assess whether participants have difficulty with walking, seeing, hearing, cognition, self-care or communication, are suitable for children aged 5 years and above, and have been used extensively in India [17].

Similarly, to assess girls' nutritional status, we used standard international indicators and methods. We measured girls' height using a Seca 213 stadiometer, their weight using a Seca 874 scale, and Mid Upper Arm Circumference (MUAC) using a standard adult tape procured from UNICEF. We defined stunting (height for age) and thinness (BMI for age) as -2 Standard Deviations (SD) below the mean sex-specific WHO Reference 2007 [18]. We defined overweight as +2 SD above the mean. In reporting BMI-for-age statistics, we excluded girls who were pregnant for the first time, and girls who had already been pregnant if it was unclear whether or not they were pregnant at the time of the survey. We calculated the proportion of girls aged 15-19 with a BMI less than 18.5. There is no standardised MUAC cut-off to identify adolescent thinness, so we used a cutoff of $<160 \mathrm{~mm}$ among girls aged 10-14 years based on nutrition guidelines for HIV-infected children [19]. Interviewers received anthropometry training and participated in a standardisation exercise with 10 adolescent girls to assess Technical Error of Measurement. The inter-observer coefficient of reliability was 0.98 for height and 0.99 for weight and MUAC. Each measurement was repeated and we calculated a mean of the two measurements. We used the Food and Nutrition Technical Assistance (FANTA) tool to measure minimum dietary diversity, i.e. the proportion of girls who had consumed five or more of 10 key food groups in the last day or night [20].

We assessed knowledge and practices related to sexual and reproductive health among all girls aged 15-19 (married and unmarried) as well as girls aged 10-14 who were married. We used questions from the Youth in India: Situation and Needs Study 2005-6 [14]. We asked girls whether they had heard about contraception, what kind, from where, and about whether they thought abortion was legal. We also asked about previous pregnancies. Married girls were asked whether they or their husband had used any methods to prevent or delay pregnancies.

For other areas of adolescent health however, there were no validated instruments or internationally recognised indicators. For example, there are no appropriate brief screening tools for adolescent mental health validated in India. We decided to use the Brief Problem Checklist (BPC), which comprises a six-item Internalising scale and a six-item Externalising scale, as well as a Total Problems scale. This tool was developed and validated for a US clinical population and was shown to be both easily administered and psychometrically strong [21]. Interviewers in our study found the BPC simple to use and participants understood the items easily. In our sample, Cronbach's alpha, a measure of internal consistency, was 0.77. The BPC has now been replaced by the Brief Problem Monitor (BPM) [22].

Collecting data on violence was equally challenging. We asked about girls' exposure to emotional, physical and sexual violence using a translated and modified version of the Child Abuse and Neglect Screening Tool Child Version (ICAST-C) [23]. The tool was adapted to shorten administration and to reflect local forms of violence such as being made to work or look after siblings, and exposure to 'societal violence' defined as witch hunting, communal violence, social boycott, being prevented from accessing public facilities or common resources, or being subjected to a community-imposed penalty.

\section{Data management and statistical methods}

We collected data using smartphones programmed with CommCare software [24]. We coded and analysed data in Stata version 14 [25]. For nutrition data, we computed height for age and BMI for age z-scores with a Stata macro for the WHO Reference 2007.

We report descriptive statistics (mean, SD, range) for each area of adolescent health need. We present results for younger (10-14 years) and older (15-19 years) adolescents as well as for the total sample because these age groups differ and there is relatively little information on the younger age group in particular.

\section{Ethical considerations}

The study was approved by an independent ethics board convened by Ekjut in Ranchi, Jharkhand, and by the Research Ethics Committee of University College London. Ekjut had been working in the study districts and collecting data on maternal and child health in tribal communities and with local data collectors for 10 years, so had a good rapport with the study communities. However, the fact that the study involved asking adolescent girls questions about potentially sensitive issues presented substantial ethical challenges.

\section{Consent}

We sought consent for each village's participation from the local village governance institutions (Panchayat and headmen) and opinion leaders after explaining the study's purpose and processes. Interviewers explained to all adolescents and any parents or husbands that the survey would include questions on health, nutrition, as well as potentially more sensitive subjects such as alcohol and tobacco use, feelings and worries about growing up, about safety, or about experiences at school and at home. 
Interviewers said that participation was voluntary, that choosing not to participate would not disadvantage the family or adolescent in any way, and that participants could stop the interview at any time or skip any questions that they did not want to answer. We obtained consent (a witnessed thumbprint) from all girls who participated in the study. For girls younger than 18 years, we also sought consent from their caregiver. For married adolescent girls younger than 18 years, we sought consent from the husband, though married adolescent girls were interviewed privately. We did not collect data from any girls if they had not themselves provided informed consent, regardless of whether or not their caregiver or husband had.

\section{Confidentiality}

Data collectors needed to be able to speak Hindi and Ho, but could not be from the villages in which interviews were being conducted in order to protect participants' confidentiality. We followed WHO ethical and safety recommendations for research on domestic violence against women by always asking questions about violence in a private space, with no third-party present, and within the bounds of a more general survey [26]. All data collected on smartphones were anonymised following downloads, and interviewers had password protected smartphones.

\section{Referrals}

Ekjut convened a local multidisciplinary child protection committee to help coordinate the referral of vulnerable adolescents identified through the research. The committee included the Child Protection Officer and Probation Officer from the District Child Protection Unit, all members and the Chairperson from the Child Welfare Committee, the Office Legal Assistant from the District Legal Services Authority, and NGO representatives. We used the data collection software (CommCare) to flag participants who had faced sexual or physical violence, as well as those with severe mental health problems or severe undernutrition to each interviewer. The interviewers and their supervisors then confidentially offered help from a trained psychosocial counsellor to visit these adolescents, discuss their needs and organise any onward referral with explicit consent from the adolescent.

\section{Results}

We estimated that 4068 girls aged 10-19 lived in our 50 study villages based on projections using data from the 2011 Indian Census [27]. In total, we identified 3932 (97\%) girls and interviewed 3324 (82\%). The most common reasons for being unavailable for interview included boarding at a hostel away from home in order to study or work, and being married and living in the marital home.

\section{Sample characteristics}

Girls had a mean age of 14.3 (SD 2.9) and 54\% were aged 10-14 (Table 1). Most (82\%) were from Scheduled Tribes, mainly the Ho tribe, or from Other Backward Classes (17.4\%). A fifth of girls aged 15-19 were married compared to $0.3 \%$ of girls aged $10-14$. The majority (85\%) lived in households with electricity (85\%) but $92 \%$ did not have access to a toilet.

\section{Education}

Twenty-three percent of older girls aged 15-19 were unable to read and $13.5 \%$ had never been to school (Table 2). Fewer younger girls aged 10-14 were illiterate (14.6\%) and 3.7\% had never attended school. The proportion of girls attending school or college reduced with age, particularly from 12 years (Fig. 1). The most common reasons for never attending school were being required for household work (53\%), being required for work on the family farm or in the family business (38\%), prohibitive school costs (24\%) and views that education was not necessary (20\%). The most common reasons for dropping out of school were linked to being required for household work, work on the family farm or in the family business. Fourty- $4 \%$ of girls had been absent from school or college in the past 2 weeks, mainly due to household work, work on the family farm or business, or personal illness. Only $1 \%$ of girls had received any vocational training in the past year.

\section{General health and nutrition}

The prevalence of disability was $0.4 \%$. Most girls reported that they felt 'quite healthy' (77\%) or 'very healthy' (13\%) (Table 3). Common health problems reported by girls included high fever (19\%), menstrual problems (16\%) and vomiting or nausea (8\%). Less than half of those who had problems said they sought help for these. Among those who did seek help, they mainly consulted informal and largely untrained allopathic providers referred to as 'village doctors' (27\%), pharmacist (10\%) or traditional healers locally termed 'Ojha'. Fourteen percent of younger girls and $15 \%$ of older girls had used alcohol in the past month.

The prevalence of thinness (<-2SD BMI for age and sex) among younger girls (14\%) was more than twice the prevalence among older girls (6\%). However, $41 \%$ of older girls had a BMI below 18.5 . Only $1 \%$ of girls aged $10-19$ were overweight $(\mathrm{BMI}>1 \mathrm{SD})$. Stunting $(<-2 \mathrm{SD}$ height for age and sex) was common, affecting a third of younger girls and $58 \%$ of older girls. Less than a quarter of all girls achieved minimum dietary diversity in the previous $24 \mathrm{~h}$. The mean MUAC measurement for younger girls was $19.8 \mathrm{~cm}$ and $23.2 \mathrm{~cm}$ for older girls. Although $38 \%$ of girls reported experiencing symptoms of anaemia (weakness, tired all the time, pale hands and face, dizziness, breathlessness when resting) only a fifth had a blood test for these symptoms. 
Table 1 Socio-economic characteristics of adolescent girls in the study area

\begin{tabular}{|c|c|c|c|c|c|c|}
\hline & \multicolumn{2}{|c|}{$\begin{array}{l}10-14 \\
\text { years }\end{array}$} & \multicolumn{2}{|c|}{$\begin{array}{l}15-19 \\
\text { years }\end{array}$} & \multicolumn{2}{|c|}{$\begin{array}{l}\text { Total }(n= \\
3324)\end{array}$} \\
\hline & $\mathrm{N}$ & $\%$ & $\mathrm{~N}$ & $\%$ & $\mathrm{~N}$ & $\%$ \\
\hline \multicolumn{7}{|l|}{ Household location } \\
\hline Main Village & 1297 & 72.8 & 1077 & 69.8 & 2374 & 71.4 \\
\hline Hamlet & 485 & 27.2 & 465 & 30.2 & 950 & 28.6 \\
\hline \multicolumn{7}{|l|}{ Class/Caste status } \\
\hline Scheduled Tribe & 1467 & 82.3 & 1264 & 82.0 & 2731 & 82.2 \\
\hline Scheduled Caste & 9 & 0.5 & 6 & 0.4 & 15 & 0.5 \\
\hline Other Backward Class & 306 & 17.2 & 272 & 17.6 & 578 & 17.4 \\
\hline \multicolumn{7}{|l|}{ Tribe $(n=2731)$} \\
\hline Ho & 1449 & 98.8 & 1254 & 99.2 & 2703 & 99.0 \\
\hline Santhal & 8 & 0.5 & 2 & 0.2 & 10 & 0.4 \\
\hline Oraon & 0 & 0.0 & 1 & 0.1 & 1 & 0.0 \\
\hline Munda & 10 & 0.7 & 6 & 0.5 & 16 & 0.6 \\
\hline Other & 0 & 0.0 & 1 & 0.1 & 1 & 0.0 \\
\hline \multicolumn{7}{|l|}{ Religion } \\
\hline Sarna & 1463 & 82.1 & 1250 & 81.1 & 2713 & 81.6 \\
\hline Hindu & 247 & 13.9 & 222 & 14.4 & 469 & 14.1 \\
\hline Christian & 47 & 2.6 & 52 & 3.4 & 99 & 3.0 \\
\hline Other & 25 & 1.4 & 18 & 1.2 & 43 & 1.3 \\
\hline \multicolumn{7}{|l|}{ Marital status } \\
\hline Not married & 1777 & 99.7 & 1196 & 77.6 & 2973 & 89.4 \\
\hline Married & 5 & 0.3 & 346 & 22.4 & 351 & 10.6 \\
\hline Owns personal mobile phone & 37 & 2.1 & 466 & 30.2 & 503 & 15.1 \\
\hline \multicolumn{7}{|l|}{ Household assets $^{a}$} \\
\hline Bicycle & 1532 & 86.0 & 1288 & 83.5 & 2820 & 84.8 \\
\hline Television & 151 & 8.5 & 147 & 9.5 & 298 & 9.0 \\
\hline Electricity & 1503 & 84.3 & 1325 & 85.9 & 2828 & 85.1 \\
\hline Motorcycle & 203 & 11.4 & 185 & 12 & 388 & 11.7 \\
\hline \multicolumn{7}{|l|}{ Sources of household income ${ }^{a}$} \\
\hline $\begin{array}{l}\text { Daily paid labour through } \\
\text { MGNREGA }^{\mathrm{b}}\end{array}$ & 745 & 41.8 & 653 & 42.3 & 1398 & 42.1 \\
\hline $\begin{array}{l}\text { Daily paid labour not through } \\
\text { MNREGA }\end{array}$ & 1411 & 79.2 & 1276 & 82.7 & 2687 & 80.8 \\
\hline Paid agricultural labour & 1163 & 65.3 & 991 & 64.3 & 2154 & 64.8 \\
\hline $\begin{array}{l}\text { Small scale trade (tela, small } \\
\text { market stall, very small shop) }\end{array}$ & 106 & 5.9 & 74 & 4.8 & 180 & 5.4 \\
\hline \multicolumn{7}{|l|}{ Type of toilet in household } \\
\hline Not improved & 41 & 2.3 & 49 & 3.2 & 90 & 2.7 \\
\hline Improved & 111 & 6.2 & 76 & 4.9 & 187 & 5.6 \\
\hline Field & 1630 & 91.5 & 1417 & 91.9 & 3047 & 91.7 \\
\hline
\end{tabular}

a Participants selected one or more options as appropriate; ${ }^{b}$ MGNREGA Mahatma Gandhi National Rural Employment Guarantee Act, a national programme to provide wage employment to households in rural area
Table 2 Educational status of adolescent girls in the study area

\begin{tabular}{|c|c|c|c|c|c|c|}
\hline & \multicolumn{2}{|c|}{$\begin{array}{l}10-14 \\
\text { years }\end{array}$} & \multicolumn{2}{|c|}{$\begin{array}{l}15-19 \\
\text { years }\end{array}$} & \multicolumn{2}{|l|}{ Total } \\
\hline & $\bar{N}$ & $\%$ & $\bar{N}$ & $\%$ & $\mathrm{~N}$ & $\%$ \\
\hline \multicolumn{7}{|l|}{ Literacy } \\
\hline Cannot read & 260 & 14.6 & 347 & 22.5 & 607 & 18.3 \\
\hline Reads with difficulty & 677 & 38.0 & 311 & 20.2 & 988 & 29.7 \\
\hline Reads easily & 845 & 47.4 & 884 & 57.3 & 1729 & 52.0 \\
\hline \multicolumn{7}{|l|}{ School attendance } \\
\hline Never attended school & 65 & 3.7 & 208 & 13.5 & 273 & 8.2 \\
\hline Previously attended school & 136 & 7.6 & 624 & 40.5 & 760 & 22.9 \\
\hline $\begin{array}{l}\text { Currently attends school or } \\
\text { college }\end{array}$ & 1581 & 88.7 & 710 & 46.0 & 2291 & 68.9 \\
\hline \multicolumn{7}{|l|}{$\begin{array}{l}\text { Reasons for never attending } \\
\text { school }(n=273)^{\mathrm{a}}\end{array}$} \\
\hline $\begin{array}{l}\text { Education not considered } \\
\text { necessary }\end{array}$ & 9 & 13.8 & 47 & 22.6 & 56 & 20.5 \\
\hline $\begin{array}{l}\text { Required for work on the family } \\
\text { farm or in the family business }\end{array}$ & 18 & 27.7 & 87 & 41.8 & 105 & 38.5 \\
\hline Costs too much money & 12 & 18.5 & 54 & 26.0 & 66 & 24.2 \\
\hline Required for household work & 35 & 53.8 & 110 & 52.9 & 145 & 53.1 \\
\hline
\end{tabular}

Reasons for dropping out of school $(n=760)^{a}$

\begin{tabular}{|c|c|c|c|c|c|c|}
\hline Required for household work & 57 & 41.9 & 228 & 36.5 & 285 & 37.5 \\
\hline $\begin{array}{l}\text { Required for work on the family } \\
\text { farm or in the family business }\end{array}$ & 31 & 22.8 & 140 & 22.4 & 171 & 22.5 \\
\hline Failed exams & 6 & 4.4 & 131 & 21.0 & 137 & 18.0 \\
\hline Illness or death of family member & 29 & 21.3 & 99 & 15.9 & 128 & 16.8 \\
\hline Got married & 2 & 1.5 & 114 & 18.3 & 116 & 15.3 \\
\hline $\begin{array}{l}\text { Absence in the past } 2 \text { weeks } \\
(n=2267)\end{array}$ & 725 & 46.0 & 274 & 39.6 & 999 & 44.1 \\
\hline \multicolumn{7}{|l|}{ eason for absence $(n=999)$} \\
\hline Festival & 106 & 14.6 & 31 & 11.3 & 137 & 13.7 \\
\hline Strikes/bandhs & 13 & 1.8 & 7 & 2.6 & 20 & 2.0 \\
\hline $\begin{array}{l}\text { Required to work on family farm } \\
\text { or in the family business }\end{array}$ & 151 & 20.8 & 76 & 27.7 & 227 & 22.7 \\
\hline Required for household work & 195 & 26.9 & 69 & 25.2 & 264 & 26.4 \\
\hline $\begin{array}{l}\text { Death or illness of a family } \\
\text { member }\end{array}$ & 28 & 3.9 & 9 & 3.3 & 37 & 3.7 \\
\hline Personal illness & 139 & 19.2 & 33 & 12.0 & 172 & 17.2 \\
\hline No reason & 43 & 5.9 & 17 & 6.2 & 60 & 6.0 \\
\hline Other & 50 & 6.9 & 32 & 11.7 & 82 & 8.2 \\
\hline $\begin{array}{l}\text { leceived vocational training in the } \\
\text { ast year }\end{array}$ & 12 & 0.7 & 33 & 2.1 & 45 & 1. \\
\hline
\end{tabular}

${ }^{\text {a }}$ Participants selected one or more options as appropriate 


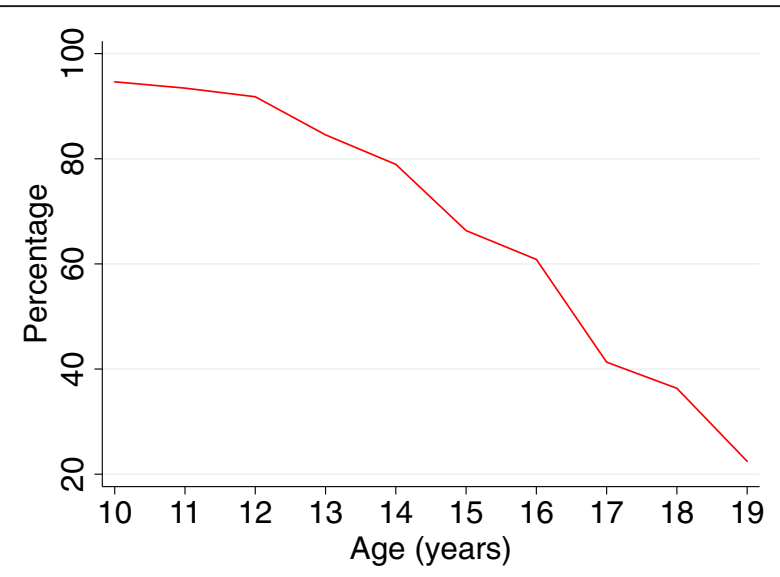

Fig. 1 School or college attendance by age among adolescent girls in Jharkhand

The mean age of menarche was 12 years (SD 1.0). Half the girls used sanitary napkins and $27 \%$ used locally made napkins. Restrictions during menstruation were uncommon and mainly pertained to participation in religious rituals.

\section{Sexual and reproductive health}

We asked all girls aged 15-19 and any married girls aged 10-14 $(n=1547)$ questions related to sexual and reproductive health (Table 4). Only 30\% of girls had heard of contraception. Among those who had heard of contraception, $92 \%$ had heard of oral contraceptive pills and $22 \%$ had heard of condoms. A quarter of girls who had heard of contraceptive pills knew that they should be taken every day. Of those who had heard of condoms, $45 \%$ knew they should be used for only one act of sexual intercourse. Thirty-eight percent of girls who had heard of IUDs knew that they are placed in the uterus. Only $7 \%$ knew that abortion is legal in India (84\% thought abortion was not legal and 9\% did not know). Friends or neighbours were the most common sources of information on contraception. Nine percent of girls had been pregnant and $68 \%$ of these girls had had a pregnancy under the age of 18 . Among married girls, only $10 \%$ had ever used contraception with their husband and oral contraceptive pills were the most common method used.

\section{Violence and mental health}

Exposure to violence in the past year was common, especially among younger girls (Table 5). Fourty-4 \% of girls aged 10-14 years had been exposed to emotional violence, $18 \%$ to physical violence and $0.3 \%$ to sexual violence. Among older girls, $37 \%$ had experienced emotional violence, $9 \%$ physical violence and $1 \%$ sexual violence. Parents, siblings and other relatives were the most common perpetrators of violence for both age groups. Compared to older girls, a higher proportion of younger girls had experienced violence perpetrated by peers
Table 3 General health, nutrition and menstrual hygiene among adolescent girls in the study area

\begin{tabular}{|c|c|c|c|c|c|c|}
\hline & \multicolumn{2}{|c|}{$\begin{array}{l}10-14 \\
\text { years }\end{array}$} & \multicolumn{2}{|c|}{$\begin{array}{l}15-19 \\
\text { years }\end{array}$} & \multicolumn{2}{|l|}{ Total } \\
\hline & $\bar{N}$ & $\%$ & $\bar{N}$ & $\%$ & $\mathrm{~N}$ & $\%$ \\
\hline \multicolumn{7}{|l|}{ GENERAL HEALTH } \\
\hline \multicolumn{7}{|l|}{ Self-rated health } \\
\hline Very Healthy & 206 & 11.6 & 220 & 14.3 & 426 & 12.8 \\
\hline Quite Healthy & 1410 & 79.1 & 1141 & 74.0 & 2551 & 76.7 \\
\hline Not Very Healthy & 166 & 9.3 & 181 & 11.7 & 347 & 10.4 \\
\hline Disability & 10 & 0.6 & 4 & 0.3 & 14 & 0.4 \\
\hline \multicolumn{7}{|l|}{ Health problem ${ }^{a}$} \\
\hline High fever & 330 & 18.5 & 301 & 19.5 & 631 & 19.0 \\
\hline Vaginal discharge & 105 & 5.9 & 154 & 10 & 259 & 7.8 \\
\hline Menstrual problems & 123 & 6.9 & 397 & 25.7 & 520 & 15.6 \\
\hline Diarrhoea & 35 & 2.0 & 47 & 3.0 & 82 & 2.5 \\
\hline Vomiting or nausea & 140 & 7.9 & 137 & 8.9 & 277 & 8.3 \\
\hline Sought help for health & 245 & 41.7 & 286 & 41.9 & 531 & 41.8 \\
\hline
\end{tabular}

Sources of help for health problems $(n=1269)^{\text {a }}$

\section{Pharmacist \\ Village doctor \\ Traditional healer (Ojha)}

Used tobacco in past month

Drank alcohol in past month

NUTRITION

Thinness $(\mathrm{BMI}<-2 \mathrm{SD})$

$(n=3275)$

Overweight (BMI > 1SD)

$(n=3275)$

$\mathrm{BMI}<18.5(n=1493)$

Stunting (height $<-2$ SD)

$(n=3323)$

Mean MUAC (SD)

MUAC $<160 \mathrm{~mm}$

Minimum dietary diversity

Symptoms of anaemia in past month ${ }^{\mathrm{b}}$

Blood test for symptoms

of anaemia in

past month $(n=1248)$

MENSTRUAL HYGIENE

Started period

Mean age started period (mean, SD)

Method of sanitary protection $(n=2220)$

Nothing

Any cloth

Locally made napkins

Sanitary napkins

$\begin{array}{llllll}56 & 9.5 & 70 & 10.3 & 126 & 9.9 \\ 161 & 27.4 & 178 & 26.1 & 339 & 26.7 \\ 22 & 3.7 & 62 & 9.1 & 84 & 6.6 \\ 7 & 0.4 & 22 & 1.4 & 29 & 0.9 \\ 245 & 13.7 & 230 & 14.9 & 475 & 14.3 \\ & & & & & \\ 254 & 14.3 & 96 & 6.4 & 350 & 10.7 \\ 34 & 1.9 & 16 & 1.1 & 50 & 1.5 \\ & & & & & \\ \mathrm{n} / \mathrm{a} & \mathrm{n} / \mathrm{a} & 609 & 40.8 & \mathrm{n} / \mathrm{a} & \mathrm{n} / \mathrm{a} \\ 590 & 33.1 & 898 & 58.2 & 1488 & 44.8 \\ & & & & & \\ 19.8 & 2.5 & 23.2 & 2.0 & 21.4 & 2.8 \\ 64 & 3.6 & \mathrm{n} / \mathrm{a} & \mathrm{n} / \mathrm{a} & \mathrm{n} / \mathrm{a} & \mathrm{n} / \mathrm{a} \\ 425 & 23.8 & 331 & 21.5 & 756 & 22.7 \\ 560 & 31.8 & 688 & 44.8 & 1248 & 37.8 \\ 102 & 18.2 & 145 & 21.1 & 247 & 19.8\end{array}$

$\begin{array}{llllll}698 & 39.2 & 1522 & 98.7 & 2220 & 66.8\end{array}$

$\begin{array}{llllll}12 & 0.9 & 12.3 & 1.0 & 12.2 & 1.0\end{array}$ 
Table 3 General health, nutrition and menstrual hygiene among adolescent girls in the study area (Continued)

\begin{tabular}{|c|c|c|c|c|c|c|}
\hline & \multicolumn{2}{|c|}{$\begin{array}{l}10-14 \\
\text { years }\end{array}$} & \multicolumn{2}{|c|}{$\begin{array}{l}15-19 \\
\text { years }\end{array}$} & \multicolumn{2}{|c|}{ Total } \\
\hline & $\mathrm{N}$ & $\%$ & $\mathrm{~N}$ & $\%$ & $\mathrm{~N}$ & $\%$ \\
\hline Other method & 20 & 2.9 & 27 & 1.8 & 47 & 2.1 \\
\hline \multicolumn{7}{|l|}{$\begin{array}{l}\text { Restriction during menstruation } \\
(n=2220)^{\mathrm{a}}\end{array}$} \\
\hline $\begin{array}{l}\text { Restricted participation in religious } \\
\text { rituals }\end{array}$ & 30 & 4.3 & 75 & 4.9 & 105 & 4.7 \\
\hline Restricted participation in sports & 8 & 1.1 & 14 & 0.9 & 22 & 1.0 \\
\hline Restricted foods & 12 & 1.7 & 17 & 1.1 & 29 & 1.3 \\
\hline Restricted access to the kitchen & 11 & 1.6 & 26 & 1.7 & 37 & 1.7 \\
\hline
\end{tabular}

a Participants selected one or more options as appropriate; ${ }^{\mathbf{b}}$ Weakness, tired all the time, pale hands and face, dizziness, breathlessness when resting

(unrelated children or adolescents). Over half had witnessed their parents or guardians shouting at each other and almost a quarter had seen or overheard their father hit or beat their mother.

We used the BPC to assess mental health problems. $12 \%$ of girls answered 'Somewhat true' or 'Very true' to all internalising items relating to depression and anxiety (e.g. items about sadness, guilt, anxiety and worthlessness). Only 3\% answered 'Somewhat true' or 'Very true' to all externalising items relating to conduct disorder and oppositional defiant disorder (e.g. items about arguing, being stubborn, having a temper). Slightly more older girls had seriously considered suicide $(6 \%)$ in the past year compared to younger girls (4\%). Of those who had considered suicide, more than half had made a suicide plan and most had attempted suicide at least once. Although the majority of girls reported that they had close friends, fewer older girls had close friends than younger girls.

\section{Discussion}

We have undertaken the most recent, comprehensive survey of adolescent health among Indian tribal communities in eastern India to date. Our study provides data for both younger and older girls, addressing an important gap in the research literature, especially for girls aged 10-14. There were key differences in the health profile of older versus younger girls in terms of violence, nutrition and school attendance, suggesting the need for more nuanced intervention approaches. We found that although the majority of girls attend school, absences were common and many dropped out of school as they got older. Younger and older girls faced violence, especially emotional and physical violence perpetrated by parents and other family members. Stunting affected almost half of girls and many had low BMIs. Although the percentage of early childbearing was relatively low in this setting, the majority of older girls had not heard about contraception, implying that
Table 4 Sexual and reproductive health knowledge and behaviours among married girls and girls aged 15-19years in the study area

\begin{tabular}{|c|c|c|}
\hline & $\mathrm{N}$ & $\%$ \\
\hline Heard of contraception $(n=1547)$ & 464 & 30.0 \\
\hline \multicolumn{3}{|l|}{ Types of contraception heard about $(n=464)^{\text {a }}$} \\
\hline Regular oral contraceptive pills & 425 & 91.6 \\
\hline Injection & 98 & 21.1 \\
\hline Condom & 100 & 21.6 \\
\hline Female sterilisation & 66 & 14.2 \\
\hline Male sterilisation & 57 & 12.3 \\
\hline Emergency contraceptive pills & 34 & 7.3 \\
\hline IUD & 27 & 5.8 \\
\hline Withdrawal & 13 & 2.8 \\
\hline \multicolumn{3}{|l|}{ Sources of information on contraception $(n=464)^{a}$} \\
\hline Teacher & 128 & 27.6 \\
\hline Mother & 103 & 22.2 \\
\hline Brother in-law & 78 & 16.8 \\
\hline Sister & 88 & 19 \\
\hline Husband & 56 & 12.1 \\
\hline Other family members & 206 & 44.4 \\
\hline Friends or neighbours & 390 & 84.1 \\
\hline Books, newspapers or magazines & 59 & 12.7 \\
\hline Television & 103 & 22.2 \\
\hline Correct knowledge about oral contraceptive pills ( $n=675$ ) & 162 & 24.0 \\
\hline Correct knowledge about condoms $(n=363)$ & 162 & 44.6 \\
\hline Correct knowledge about IUDs $(n=182)$ & 69 & 37.9 \\
\hline \multicolumn{3}{|l|}{ Knowledge about legality of abortion ( $n=1547)$} \\
\hline Thinks abortion is legal & 104 & 6.7 \\
\hline Thinks abortion is not legal & 1302 & 84.2 \\
\hline Does not know or cannot say & 141 & 9.1 \\
\hline Ever been pregnant $(n=1547$ ) & 138 & 8.9 \\
\hline Had a pregnancy before age $18(n=138)$ & 94 & 68.1 \\
\hline \multicolumn{3}{|l|}{ First pregnancy wanted or unwanted $(n=138)$} \\
\hline Neither mother nor father wanted the pregnancy & 6 & 4.4 \\
\hline Only mother wanted pregnancy & 2 & 1.5 \\
\hline Only father wanted pregnancy & 3 & 2.2 \\
\hline Both mother and father wanted pregnancy & 127 & 92.0 \\
\hline $\begin{array}{l}\text { You or your husband ever used methods to prevent or } \\
\text { delay pregnancy }(n=341)\end{array}$ & 34 & 10.0 \\
\hline
\end{tabular}

a Participants selected one or more options as appropriate, IUD intrauterine device

more accessible forms of information on sexual health and family planning are necessary.

Our study benefits from a large community-based sample of girls from largely tribal communities, but has some limitations. Most of the girls were from Ho tribe communities which may limit the generalisability of the 
Table 5 Violence exposures and mental health among girls aged 10-19years in the study area

\begin{tabular}{|c|c|c|c|c|c|c|}
\hline & \multicolumn{2}{|c|}{$\begin{array}{l}10-14 \\
\text { years }\end{array}$} & \multicolumn{2}{|c|}{$\begin{array}{l}15-19 \\
\text { years }\end{array}$} & \multicolumn{2}{|l|}{ Total } \\
\hline & $\mathrm{N}$ & $\%$ & $\mathrm{~N}$ & $\%$ & $\mathrm{~N}$ & $\%$ \\
\hline \multicolumn{7}{|l|}{ VIOLENCE } \\
\hline $\begin{array}{l}\text { Any form of violence in the past } \\
\text { year }(n=3288)\end{array}$ & 836 & 47.6 & 569 & 37.2 & 1405 & 42.7 \\
\hline $\begin{array}{l}\text { Emotional violence in past year } \\
(n=3293)\end{array}$ & 767 & 43.5 & 543 & 35.5 & 1310 & 39.8 \\
\hline $\begin{array}{l}\text { Physical violence in past year } \\
(n=3299)\end{array}$ & 325 & 18.4 & 135 & 8.8 & 460 & 13.9 \\
\hline $\begin{array}{l}\text { Sexual violence in past year } \\
(n=3323)\end{array}$ & 6 & 0.3 & 17 & 1.1 & 23 & 0.7 \\
\hline
\end{tabular}

Perpetrators of emotional, physical or sexual violence in last year ${ }^{\text {a }}$

Parents ( $n=1405)$
Sibling $(n=1405)$
Husband $(n=1405)$
Parent in-law $(n=1402)$
Other relative ( $n=1405)$
Unrelated child/adolescent
$(n=1405)$
Employer ( $n=1405)$
Teacher ( $n=1405)$
Unrelated adult ( $n=1405)$
Sought medical attention as a
esult of violence ( $n=597)$
Societal violence in past year
$(n=3084)$
Seen or overheard parents/
guardians shouting at each other
$(n=3324)$

Seen or overheard father hit or beat mother $(n=3324)$

Seen or overheard mother hit or beat father $(n=3324)$

\section{MENTAL HEALTH}

Answered 'Somewhat true' or Very true' to all BPC items $(n=3131)$

Answered 'Somewhat true' or Very true' to all externalising BPC items $(n=3131)^{\mathrm{b}}$

Answered 'Somewhat true' or Very true' to all internalising items $(n=3131)^{c}$

Seriously considered suicide in past year $(n=3324)$

Made a suicide plan in past year $(n=163)$

No. of times attempted suicide in past year $(n=163)$

Never

$\begin{array}{llllll}621 & 74.3 & 356 & 62.6 & 977 & 69.5 \\ 374 & 44.7 & 235 & 41.3 & 609 & 43.3 \\ 2 & 0.2 & 59 & 10.4 & 61 & 4.3 \\ 0 & 0 & 40 & 7.1 & 40 & 2.9 \\ 293 & 35 & 227 & 39.9 & 520 & 37 \\ 232 & 27.8 & 91 & 16 & 323 & 23 \\ 3 & 0.4 & 4 & 0.7 & 7 & 0.5 \\ 55 & 6.6 & 14 & 2.5 & 69 & 4.9 \\ 75 & 9 & 41 & 7.2 & 116 & 8.3 \\ 29 & 7.5 & 22 & 10.4 & 51 & 8.5 \\ 132 & 8.1 & 132 & 9.1 & 264 & 8.6\end{array}$

$\begin{array}{llllll}1005 & 56.4 & 777 & 50.4 & 1782 & 53.6\end{array}$

$\begin{array}{llllll}503 & 28.2 & 320 & 20.8 & 823 & 24.8\end{array}$

$\begin{array}{llllll}201 & 11.3 & 87 & 5.6 & 288 & 8.7\end{array}$

$\begin{array}{llllll}41 & 2.4 & 23 & 1.6 & 64 & 2.0\end{array}$

$\begin{array}{llllll}71 & 4.2 & 38 & 2.6 & 109 & 3.5\end{array}$

$207 \quad 12.3 \quad 174 \quad 12.0 \quad 381 \quad 12.2$

$\begin{array}{llllll}66 & 3.7 & 97 & 6.3 & 163 & 4.9\end{array}$

$\begin{array}{llllll}34 & 51.5 & 60 & 61.9 & 94 & 57.7\end{array}$

$\begin{array}{llllll}14 & 21.2 & 16 & 16.5 & 30 & 18.4\end{array}$
Table 5 Violence exposures and mental health among girls aged 10-19years in the study area (Continued)

\begin{tabular}{|c|c|c|c|c|c|c|}
\hline & \multicolumn{2}{|c|}{$\begin{array}{l}10-14 \\
\text { years }\end{array}$} & \multicolumn{2}{|c|}{$\begin{array}{l}15-19 \\
\text { years }\end{array}$} & \multicolumn{2}{|c|}{ Total } \\
\hline & $\mathrm{N}$ & $\%$ & $\mathrm{~N}$ & $\%$ & $\mathrm{~N}$ & $\%$ \\
\hline 1 time & 21 & 31.8 & 40 & 41.2 & 61 & 37.4 \\
\hline 2 or 3 times & 30 & 45.5 & 27 & 27.8 & 57 & 35.0 \\
\hline 4 or 5 times & 0 & 0.0 & 8 & 8.2 & 8 & 4.9 \\
\hline 6 or more times & 1 & 1.5 & 6 & 6.2 & 7 & 4.3 \\
\hline
\end{tabular}

Think parents or

guardians understand problems

$(n=3324)$

\begin{tabular}{lllllll} 
Never & 192 & 10.8 & 149 & 9.7 & 341 & 10.3 \\
Rarely & 162 & 9.1 & 105 & 6.8 & 267 & 8.0 \\
Sometimes & 171 & 9.6 & 136 & 8.8 & 307 & 9.2 \\
Most of the time & 384 & 21.5 & 315 & 20.4 & 699 & 21.0 \\
Always & 873 & 49.0 & 837 & 54.3 & 1710 & 51.4 \\
Has close friends $(n=3324)$ & 1553 & 87.1 & 1191 & 77.2 & 2744 & 82.6 \\
\hline
\end{tabular}

a Participants selected one or more options as appropriate; ${ }^{\mathbf{b}_{\text {items relate }}}$ to conduct disorder and oppositional defiant disorder and enquire about tendency to argue, destroy things, disobey parents or people at school, stubbornness, anger and threatening to hurt people; ${ }^{{ }^{i}}$ items relate to depression and anxiety and enquire about feeling worried, unhappy, sad or depressed, fearful or anxious, self-conscious or embarrassed, worthless or inferior, and guilty

study results to girls from other tribal communities. A minority of girls stayed in hostels outside the study villages and could not be included in the study. We were unable to identify a concise and locally validated tool to comprehensively assess mental health. We therefore used the BPC, which has good psychometric properties. We are planning to validate the BPM, a replacement for the BPC, in an adolescent population in Jharkhand. Compared to previous surveys in Jharkhand, we identified a relatively low prevalence of early marriage [28]. Ho communities, the most common tribal group in the study area, may encourage relatively delayed marriage compared to other groups in Jharkhand. The discrepancy could also be due to recent targeted programmes and campaigns (http://www.oxfamindia.org/blog/542/singing-their-wayout-child-marriage) [29, 30], an increasing number of girls staying in school [28], and families knowing the legal age of marriage and being reluctant to identify underage married girls in their household.

The prevalence of stunting in our sample was relatively high compared to a previous estimate of $33.2 \%$ among girls aged 15-19 in India [31]. This suggests a large burden of chronic undernutrition in rural Jharkhand, which may have adverse effects on adolescent mental development and educational attainment, with potential long term consequences for employment and earning capacity [32].

The prevalence of thinness (below - 2 SD BMI for age) in our study was higher in younger girls (14\%) compared to 
older girls (6.4\%), though lower overall compared to previous surveys. India's Clinical, Anthropometric and Biochemical (CAB) 2014 Survey reported a prevalence of $28 \%$ thinness among girls aged 5-18 years living in rural Jharkhand, and 19\% in rural West Singhbhum district [33]. A study of nutritional status in tribal adolescents aged 10-17 across India reported a higher prevalence of $42 \%$ thinness ( $<5$ th BMI age percentiles of National Health and Nutrition Examination Survey, NHANES) among girls, however these data were collected in 1998-99 [34].

We were unable to clinically assess anaemia, though we would expect the prevalence to be high based on findings from the $C A B$ survey suggesting a prevalence of $86 \%$ among girls aged 10-17 years living in rural West Singhbhum [33]. Evidence suggests that iron alone, iron and folic acid, zinc, and multiple micronutrient supplementation can increase serum haemoglobin concentration among adolescent girls [35, 36]. However, in order to identify an appropriate intervention, further investigation into the aetiology of anaemia in this population is warranted. In South Asia, community-based nutrition education and behaviour change interventions have improved girls' knowledge about nutrition, as well as their dietary practices [36]. Further research is needed to assess the effects of food supplementation and cash transfers on adolescent undernutrition. There is also a need for country and regional data to validate threshold MUAC scores and we hope our data will contribute to this.

Violence is a key health problem facing girls across India. The effects of violence can have both short and long term consequences including injuries, sexually transmitted infections, depression, substance misuse, self-harm, suicide attempts and non-communicable diseases [37-41]. Emotional violence was highly prevalent in our study and included being insulted, humiliated and intimidated. Eve-teasing is a common form of emotional and sexual violence against girls, and includes "staring, stalking, passing comments, and inappropriate physical touch" by boys and men [42]. Consequences for girls may include restrictions on mobility, inability to go to school or work, blame and disrespect from family members [42]. Parents were the most common perpetrators of violence against girls in our study and around a quarter reported witnessing violence between their parents. Community-based interventions that aim to change attitudes and norms that condone violence and gender inequity, and that promote non-violent behaviours could help to reduce violence [43]. Targeting parents as well as adolescents to try to reduce perpetration and exposures in the home may also be beneficial.

Few girls aged 15-19 knew about contraception despite more than a fifth being married. This could reflect the fact that talking about contraception is taboo in the study communities, and girls either had little knowledge on the topic or were reluctant to answer questions about it. A national survey found that young people had limited awareness of most sexual and reproductive health matters [14]. Government strategies to improve adolescent sexual and reproductive health include adolescent friendly health services, community peer-led education sessions and a school-based education programme [4446]. However, girls may have limited agency to access services and make decisions related to sexual and reproductive health [47]. Future strategies should focus on building adolescents' self-efficacy as well as improving their sexual and reproductive health knowledge.

Programmes to reduce early marriage and early childbearing often focus on keeping girls in school through conditional cash transfers, school vouchers and other incentives [48]. Our findings suggest that the main reasons for absenteeism, dropping out of school and never attending school are due to employment and domestic work. Research to understand the cost benefits of incentive schemes compared to out-of-school work for adolescents and their families is needed.

What are the implications of our study for future community interventions? India's national adolescent health and development programme - Rashtriya Kishor Swasthya Karyakram (RKSK) - outlines facility- and communitybased interventions to improve adolescent health across a range of areas of health need [46]. In Jharkhand, the programme has not yet reached full coverage, and data on the health of girls in this setting are needed to inform intervention planning and scale-up. Our study identified a wide range of adolescent health needs relevant to RKSK. The programme's Peer Educator Activity Book, including nutrition, sexual and reproductive health, mental health and violence is therefore appropriate [49]. However, our findings suggest that the content may need to be tailored depending on setting and age and sex of adolescents. For example, overnutrition is a key topic in the Activity Book that currently has limited relevance in rural Jharkhand. Whilst content on alcohol use may be relevant for girls in this setting, activities related to use of tobacco and other recreational drugs may be less useful. Discussions on contraception may be more relevant and acceptable to older girls. Activities to encourage younger girls to stay in school may be beneficial. Formative work to locally adapt the RKSK curriculum is essential, as is implementation research to optimise delivery of the intervention to different groups of adolescents.

\section{Conclusion}

Our study has identified key areas of focus to improve health, nutrition and wellbeing among adolescent girls living in eastern India: reducing violence, early 
marriage and undernutrition, as well as improving mental health, knowledge about contraception and retention of girls in school. Whilst national government programmes to improve adolescent health broadly cover the main health issues in this population, local assessment of priorities and adaptation of programme content are necessary to ensure programmes are relevant and effective.

\section{Additional file}

Additional file 1: Survey instrument. English language version of survey instrument. (XLSX $27 \mathrm{~kb}$ )

\section{Abbreviations}

BMI: Body Mass Index; BPC: Brief Problem Checklist; BPM: Brief Problem Monitor; FANTA: Food and Nutrition Technical Assistance; ICAST-C: ISPCAN Child Abuse Screening Tools Children's Version; MGNREGA: Mahatma Gandhi National Rural Employment Guarantee Act; MUAC: Mid-Upper Arm Circumference; NHANES: National Health and Nutrition Examination Survey, NHANES; RKSK: Rashtriya Kishor Swasthya Karyakram; US: United States

\section{Acknowledgements}

We thank the adolescents and their family members who took part in the study.

\section{Authors' contributions}

AP and NN conceptualised the study and developed the methods with HP, SR1, SR2, SS, SG, PT and KR-C (SR1 Suchitra Rath; SR2 Shibanand Rath). KR-C and HP analysed the data. HP managed data collection and cleaning, supported by KR-C, SR1, SR2, SS, SG, AP and NN. KR-C wrote the first draft of the article. AP and NN aCquired the funding. All authors read and approved the final draft.

\section{Funding}

The study was funded by the Children's Investment Fund Foundation. The funder had no role in the design of the study, collection, analysis and interpretation of data, or in writing the manuscript.

\section{Availability of data and materials}

The dataset analysed during the current study is not publicly available, as it constitutes the baseline survey of an ongoing trial. However, it may be available from the corresponding author on reasonable request.

\section{Ethics approval and consent to participate}

The study was approved by the Research Ethics Committee of University College London (reference number 2656/002) and an independent ethics board in India convened by Ekjut, a civil society organisation in Ranchi, Jharkhand (reference IEC/ EKJUT/). All adolescent girls provided informed consent (a witnessed thumbprint). For girls younger than 18 years, we also sought verbal consent from their parent or guardian. Verbal consent was deemed by the research team to be an acceptable and valid approach in this context. Indian colleagues leading the data collection advised us to seek consent from the husband for married girls under 18 in order not to cause conflict at home. In this context, 'guardian' was interpreted as meaning husband. The local ethics board discussed and approved all consent procedures in this study.

\section{Consent for publication}

Not applicable.

\section{Competing interests}

The authors declare that they have no competing interests.

\section{Author details}

'Department of Global Health and Social Medicine, King's College London, Bush House NE Wing, London WC2B 4BG, UK. Ekjut, Chakradharpur, Jharkhand, India. ${ }^{3}$ Institute for Global Health, University College London, London, UK
Received: 17 December 2018 Accepted: 27 May 2019

Published online: 31 May 2019

\section{References}

1. World Health Organization: The global strategy for women's, children's and adolescents' health (2016-2030): survive, thrive, transform.; 2015.

2. Viner RM, Coffey C, Mathers C, Bloem P, Costello A, Santelli J, Patton G. 50-year mortality trends in children and young people: a study of 50 low-income, middle-income, and high-income countries. Lancet. 2011;377(9772):1162-74.

3. Patton GC, Sawyer SM, Santelli JS, Ross DA, Afifi R, Allen NB, Arora M, Azzopardi P, Baldwin W, Bonell C, et al. Our future: a lancet commission on adolescent health and wellbeing. Lancet. 2016;387(10036):2423-78.

4. Fall CH, Sachdev HS, Osmond C, Restrepo-Mendez MC, Victora C, Martorell $R$, Stein AD, Sinha S, Tandon N, Adair L, et al. Association between maternal age at childbirth and child and adult outcomes in the offspring: a prospective study in five low-income and middle-income countries (COHORTS collaboration). Lancet Glob Health. 2015;3(7):e366-77.

5. Global Accelerated Action for the Health of Adolescents (AA-HA!): guidance to support country implementation. Geneva: World Health Organization; 2017. Licence: CC BY-NC-SA 3.0 IGO.

6. UNICEF: Progress for children: a report card for adolescents.; 2012.

7. Singh S, Gopalkrishna G. Health behaviours and problems among young people in India: cause for concern and call for action. Indian J Med Res. 2014:140(2):185-208

8. Ministry of Health and Family Welfare: National Family Health Survey - 4 2015-16: India fact sheet.; 2017.

9. Ministry of Women and Child Development, UNICEF. Rapid Survey on Children 2013-2014. New Delhi: Government of India; 2014

10. Ministry of Home Affairs, Government of India: Primary census data highlights India (chapter 2 - scheduled castes and scheduled tribes population).; 2011.

11. Van de Poel E, Speybroeck N. Decomposing malnutrition inequalities between scheduled castes and tribes and the remaining Indian population. Ethn Health. 2009;14(3):271-87.

12. ST-14 scheduled tribe population by religious community. Census of India [http://www.censusindia.gov.in/2011census/SCST-Series/ST14.html].

13. International Institute for Population Sciences (IIPS): National Family Health Survey (NFHS-3) India 2005-2006:; 2008.

14. International Institute for Population Sciences (IIPS). Population Council: Youth in India: Situation and Needs 2006-2007. Mumbai: IIPS; 2010

15. Patton GC, Coffey C, Cappa C, Currie D, Riley L, Gore F, Degenhardt L, Richardson D, Astone N, Sangowawa AO, et al. Health of the world's adolescents: a synthesis of internationally comparable data. Lancet. 2012; 379(9826):1665-75.

16. [http://www.washingtongroup-disability.com/washington-group-questionsets/short-set-of-disability-questions/]

17. Miller K, Mont D, Maitland A, Altman B, Madans J. Results of a cross-national structured cognitive interviewing protocol to test measures of disability. Qual Quant. 2011:45(4):801-15.

18. Growth reference 5-19 years: application tools [http://www.who.int/ growthref/tools/en/].

19. The ENN, NutritionWorks: Harmonised Training Package (HTP) version 2: Module 6 "Measuring malnutrition: individual assessment of acute malnutrition".; 2011

20. FAO, FHI 360. Minimum Dietary Diversity for Women: A Guide for Measurement. Rome: FAO: 2016.

21. Chorpita BF, Reise S, Weisz JR, Grubbs K, Becker KD, Krull JL. Research network on youth mental health: evaluation of the brief problem checklist: child and caregiver interviews to measure clinical progress. J Consult Clin Psychol. 2010:78(4):526-36.

22. Achenbach TM, McConaughy SH, Ivanova MY, Rescorla LA. Manual for the brief problem monitor (BPM). Burlington, $\mathrm{VT}$ : University of Vermont Research Center for Children, Youth, \& Families; 2011

23. International Society for the Prevention of Child Abuse and Neglect: ICASTC. The ISPCAN Child Abuse Screening Tool_child version. Manual and proposed guidelines for pilot administration. Aurora: CO; 2006.

24. CommCare [http://www.dimagi.com/products].

25. StataCorp. Stata statistical software: release 14. In: College Station. TX: StataCorp LP: 2015.

26. World Health Organization. Putting women first: ethical and safety recommendations for research on domestic violence against women. Geneva: World Health Organization; 2001. 
27. Directorate of census operations Jharkhand: district census handbook: Pashchimi Singhbhum. In.; 2011.

28. (IIPS) IIfPS: National Family Health Survey - 4: 2015-16. State Fact Sheet: Jharkhand. In.; 2017.

29. Plan International. Children in difficult circumstances project [http://www. planindia.org/children-difficult-circumstances-projects].

30. Empowering girls to choose their own future: ending child marriage [https://simavi.org/wp-content/uploads/2015/12/Factsheet_Simavi_ChildMarriage-def.pdf].

31. Black RE, Victora CG, Walker SP, Bhutta ZA, Christian P, de Onis M, Ezzati M, Grantham-McGregor S, Katz J, Martorell R, et al. Maternal and child undernutrition and overweight in low-income and middle-income countries. Lancet. 2013;382(9890):427-51.

32. Akseer N, Al-Gashm S, Mehta S, Mokdad A, Bhutta ZA. Global and regional trends in the nutritional status of young people: a critical and neglected age group. Ann N Y Acad Sci. 2017;1393(1):3-20.

33. International Institute for Population Sciences. Clinical, anthropometric and Biochemical (CAB) 2014. Mumbai; 2014.

34. Rao KM, Balakrishna N, Laxmaiah A, Venkaiah K, Brahmam GN. Diet and nutritional status of adolescent tribal population in nine states of India. Asia Pac J Clin Nutr. 2006;15(1):64-71.

35. Lassi ZS, Moin A, Das JK, Salam RA, Bhutta ZA. Systematic review on evidence-based adolescent nutrition interventions. Ann N Y Acad Sci. 2017;1393(1):34-50

36. Aguayo V, Paintal K. Nutrition in adolescent girls in South Asia. BMJ. 2017;357:j1309

37. Felitti VJ, Anda RF, Nordenberg D, Williamson DF, Spitz AM, Edwards V, Koss MP, Marks JS. Relationship of childhood abuse and household dysfunction to many of the leading causes of death in adults: the adverse childhood experiences (ACE) study. Am J Prev Med. 1998;14(4):245-58.

38. Hillis S, Mercy JA, Amobi A, Kress H. Global prevalence of past-year violence against children: a systematic review and minimum estimates. Pediatrics. 2016;137(3):e20154079.

39. Lim S, Vos T, Flaxman AD, Danaei G, Shibuya K, Adair-Rohani H, AlMazroa MA, Amann M, Anderson HR, Andrews KG, et al. A comparative risk assessment of burden of disease and injury attributable to 67 risk factors and risk factor clusters in 21 regions, 1990-2010: a systematic analysis for the global burden of disease study 2010. Lancet. 2012;380:2224-60.

40. Norman RE, Byambaa M, De R, Butchart A, Scott J, Vos T. The long-term health consequences of child physical abuse, emotional abuse, and neglect: a systematic review and meta-analysis. PLoS Med. 2012;9(11):e1001349.

41. Norton R, Kobusingye O. Injuries. N Engl J Med. 2013;368(18):1723-30.

42. Talboys SL, Kaur M, VanDerslice J, Gren LH, Bhattacharya H, Alder SC. What is eve teasing? A mixed methods study of sexual harassment of young women in the rural Indian context. SAGE Open. 2017;7(1):1-10.

43. Ellsberg M, Arango DJ, Morton M, Gennari F, Kiplesund S, Contreras M, Watts C. Prevention of violence against women and girls: what does the evidence say? Lancet. 2015;385(9977):1555-66

44. National Rural Health Mission: Implementation guide on RCH II: adolescent reproductive sexual health strategy: 2006.

45. Tripathi N, Sekher TV. Youth in India ready for sex education? Emerging evidence from national surveys. PLoS One. 2013;8(8):e71584.

46. National Health Mission: RKSK operational framework: translating strategy into programmes.; 2014.

47. Banerjee SK, Anderson KL, Warvadekar J, Aich P, Rawat A, Upadhyay B. How prepared are young, rural women in India to address their sexual and reproductive health needs? A cross-sectional assessment of youth in Jharkhand. Reprod Health. 2015;12:97. Published 2015 Oct 17. https://doi. org/10.1186/s12978-015-0086-8

48. Kalamar AM, Lee-Rife S, Hindin MJ. Interventions to prevent child marriage among young people in low- and middle-income countries: a systematic review of the published and gray literature. J Adolesc Health. 2016;59(3):S16-21.

49. National Health Mission: RKSK Peer Educator Activity Book - a set of life skill based activities. In.

\section{Publisher's Note}

Springer Nature remains neutral with regard to jurisdictional claims in published maps and institutional affiliations.

\section{Ready to submit your research? Choose BMC and benefit from:}

- fast, convenient online submission

- thorough peer review by experienced researchers in your field

- rapid publication on acceptance

- support for research data, including large and complex data types

- gold Open Access which fosters wider collaboration and increased citations

- maximum visibility for your research: over $100 \mathrm{M}$ website views per year

At BMC, research is always in progress.

Learn more biomedcentral.com/submissions 